\title{
The Direct and Indirect Effect of Zakat on the Household Consumption of Mustahik (A Study of Zakat Recipients from BAZNAS Probolinggo Municipality)
}

\author{
Elok Nurlita and Marlina Ekawaty \\ Brawijaya University
}

\begin{abstract}
This research aims to analyze the direct and indirect effects of zakat on the household consumption of mustahik. The research adopts a quantitative approach and uses path analysis. Data were obtained from 50 mustahik (zakat recipients) at BAZNAS Probolinggo Municipality using the proportional random sampling method. The results show that zakat and number of household members directly and indirectly affect the household consumption of mustahik. Furthermore, household income as an intermediate variable also affects the household consumption of mustahik, whereas education and age have no effect, either directly or indirectly. The lack of effect of education on consumption can be attributed to the mustahiks' jobs, for which no education/special skills are required; thus, a high level of education does not affect household income and consumption. Similarly, the lack of effect of age on predicted consumption is because many mustahik are not at a productive age and do not work; increasing age does not therefore increase income and consumption.
\end{abstract}

Keywords: Poverty, Consumptive Zakat, Productive Zakat, Household Consumption

\section{INTRODUCTION}

Household consumption is the driving force of the economy in many countries, including in Indonesia. This can be seen by the dominance of household consumption in the makeup of Indonesia's national income. The contribution ratio of each component of expenditure in Indonesia's 2016 Gross Domestic Product (GDP) can be seen in the following table.

Table 1. Gross Domestic Product by Type of Expenditure at Current Market Prices in 2016

\begin{tabular}{lcr}
\hline \multicolumn{1}{c}{ Type of Expenditure } & $\begin{array}{c}\text { Value (in Billion } \\
\text { Rupiahs) }\end{array}$ & Percentage of GDP \\
\hline Household Consumption Expenditure & $7,009,577.50$ & 56.50 \\
NPISH Consumption Expenditure & $144,470.14$ & 1.16 \\
Government Consumption Expenditure & $1,172,420.34$ & 9.45 \\
Gross Fixed Capital Formation & $4,040,497.83$ & 32.57 \\
Changes in Inventories & $214,104.70$ & 1.73 \\
Exports of Goods and Services & $2,367,331.78$ & 19.08 \\
Less: Imports of Goods and Services & $-2,271,177.86$ & -18.31 \\
Statistical Discrepancies & $-270,414.63$ & -2.18 \\
\hline \multicolumn{1}{c}{ Gross Domestic Product } & $12,406,809.80$ & 100.00 \\
\hline
\end{tabular}

Source: Statistics of Indonesia, 2017 (Processed Data) 
Table 1 shows that, compared to other types of expenditure, household consumption accounts for the biggest contribution to the makeup of Indonesia's GDP, reaching $56.50 \%$. Given this large proportion, household consumption has a major impact on the stability of the economy. In contrast to exogenous government consumption, household consumption is endogenous, meaning that it is closely related to the factors that influence it. This means that economic theory and models can be developed to generate an understanding of the relationship between the level of consumption and the factors that influence it (Rahardja \& Manurung, 2008). Household consumption is carried out by all households, both rich and poor. The number of poor Indonesians in September 2016 stood at 27,764,320 people (Statistics of Indonesia, 2017). Based on Presidential Decree of the Republic of Indonesia Number 15 Year 2010 on the Acceleration of Poverty Reduction, many programs have been implemented by the government aimed at reducing the number of poor people, including family-based integrated social assistance programs, community empowerment-based poverty eradication programs, poverty reduction programs based on the empowerment of micro and small businesses, and other programs that can either directly or indirectly improve the economic activities and welfare of the poor.

Statistics of Indonesia uses the basic needs approach to measure poverty. In this approach, poverty is defined as an economic inability to meet basic food and non-food needs, as measured by household consumption expenditure. As such, poor people are those with an average monthly per capita expenditure below the poverty line.

In terms of human development, Islam features a specific and important instrument that is designed to tackle poverty, namely zakat, the most important target for which is the poor and needy.
Zakat is a compulsory donation for Muslims, assuming they meet certain criteria. Zakat means purifying your wealth for the will of Allah SWT, with those who are poor and suffering eligible to receive zakat (Hafidhuddin, 2002). Allah says in Surah At-Taubah Verse 60,

"The alms of zakat are only for the
poor, the needy, zakat board, those
whose hearts are to be reconciled, to
free the captives and the debtors, and
for the cause of Allah, and the
wayfarer; a duty imposed by Allah.
Allah is Knower and Wise." (QS. at-
Taubah 9:60)

The giving of zakat is aimed at meeting the basic needs of the poor, the needy, and other așhnaf (group). Zakat is considered capable of alleviating poverty as it is a legal means that is legalized by the formation of capital. Capital is derived not only from the processing and utilization of natural resources but can also be redistributed to those who are entitled to receive it out of the wealth of society. Zakat is able to maximize the quality of human resources through the procurement of facilities and infrastructure for the community, increase productivity, and increase public income in general (Amalia \& Mahalli, 2012). If zakat is well managed and trustworthy, it will lead to improved welfare of the people, an improved work ethic, and become a means of economic distribution within the society.

The potential of zakat to solve the problem of poverty has yet to be fully realized due to the fact that many Moslems continue to channel funds by means other than through official institutions, which means there is no appropriate form of record-keeping. Moslem society tends to distribute zakat in private so that the zakat received by mustahik is used only for the purposes of present consumption and carries no potential for its value to grow over time. The zakat given by muzakki (zakat payer) should not only be channeled 
as consumptive funds but also in the form of productive funds, such as the provision of venture capital. In this case, zakat management institutions are required to act as an intermediary and to channel some of the wealth of a capable society to those who are in need.

The National Board of Zakat (BAZNAS) is a zakat management agency that was officially established by the government to manage zakat derived from the national, provincial, and municipality/district levels. In addition to managing zakat, BAZNAS manages infaq/alms funds. One of the BAZNAS located at the municipality/district level is BAZNAS Probolinggo Municipality. BAZNAS Probolinggo Municipality has officially established and managed zakat and infaq/alms since 2012, with an emphasis on performance credibility and management accountability, as well as transparent and accountable financial management. The funds collected in 2016 reached $\mathrm{Rp} 1,604,059,000$ (BAZNAS Probolinggo Municipality, 2016).

Probolinggo Municipality has a very large Moslem population, measured in both absolute numbers and as a percentage, i.e., 215,185 people, or $97 \%$ of the population. It therefore has great potential to raise significant levels of zakat funds. The large size of the Moslem population of Probolinggo Municipality and the amount of zakat funds collected by BAZNAS Probolinggo Municipality have the potential to reduce the number of poor. The number of poor people in Probolinggo Municipality in 2015 was 18,370 (Statistics of Probolinggo Municipality, 2016).

Studies have been conducted examining the effect of zakat on consumption. These include research by Pambudi (2013) on the productive zakat recipients from BAZNAS Kebumen District, which showed that productive zakat significantly affects mustahiks' income, consumption, saving, and infaq. Research conducted by Suprayitno et al. (2013) in Malaysia revealed that the distribution of zakat has an effect on aggregate consumption; although the effect was very small, it was stated that theoretically, the tendency of consumption mustahik is higher than muzakki. The small effect of the distribution of zakat on consumption may be due to the use of aggregate consumption data from both Moslems and non-Moslems, while the collected zakat is distributed to meet the needs of Moslems only. These studies analyzed only the direct effect of zakat on consumption, whereas zakat also has an indirect effect on consumption through income. Productive zakat, which is distributed in the form of venture capital, will increase the production factor (capital) in mustahiks' businesses, which in turn will increase the mustahiks' output and income. Eventually, this increase in income will lead to an increase in mustahiks' household consumption.

\section{LITERATURE REVIEW}

\section{Consumption Theory}

Consumption is defined as any behavior of a person whereby goods and services are used/utilized to meet the needs of his life (Sumar'in, 2013). Consumption expenditure comprises government consumption and household/private consumption, but this discussion covers only household consumption expenditure. Household consumption expenditure is classified as the value of spending that is carried out by households aimed at making purchases to satisfy their various needs within a certain period of time, more commonly referred to in macroeconomic analysis as household consumption (Sukirno, 2011). Rahardja and Manurung (2008) outline the consumption theory as proposed by John Maynard Keynes. This theory is usually termed the Keynesian Consumption Function. According to Keynes, current consumption is affected by current disposable income. This gives the 
function of $\mathrm{C}=\mathrm{f}(\mathrm{Y})$, where consumption is influenced by income but there is also a minimum level of consumption that takes place independently of income. That is, a certain level of consumption must take place even if the income level is equal to 0 , which is termed autonomous consumption. If disposable income increases, consumption will also increase, but consumption will not increase at the same rate as disposable income, with consumption increasing by a lesser amount, such that the following equation applies.

where

$$
\mathrm{C}=\mathrm{a}+\mathrm{bYd}
$$

C : consumption

a : autonomous consumption

b : marginal propensity to consume (MPC), $(0 \leq \mathrm{b} \leq 1)$

$\mathrm{Yd}$ : disposable income.

Furthermore, Rahardja and Manurung (2008) outline several factors that affect household consumption expenditure, such as household income, household wealth, durable consumption amount in society, interest rate, household expectation about the future, government policy to reduce income gaps, the size and composition of the population (age, education, and residence area), and sociocultural factors.

\section{Islamic Consumption Theory}

Iqbal (1985) describes the Islamic consumption theory as proposed by Ausaf and Metwally, whereby mustahiks' MPC is higher than that of muzakkis so that the marginal (and average) propensity to consume and aggregate consumption in an Islamic economy will be higher than in a secular economy. It takes Keynes's consumption function in a secular economy as its starting point: $\mathrm{C}_{\mathrm{S}}=\mathrm{a}+\mathrm{bY}$. In order to arrive at the aggregate consumption function, the population is bifurcated into two groups, i.e., muzakki (zakat payers) and mustahik (zakat recipients). The muzakki transfer a certain proportion $(\alpha)$ of their income to the mustahik due to the compulsory levy of zakat. The consumption function in an Islamic economy therefore becomes:

$$
C_{I}=a+b(\beta Y-\alpha Y)+\delta[(1-\beta) Y+\alpha Y]
$$

$\mathrm{C}$ is the consumption function, which is a function of the income of the muzakki and mustahik. The muzakkis' income is represented in the equation by $(\beta Y-\alpha Y)$, whereby the net muzakki income is the amount of the muzakkis' income $(\beta Y)$ minus the amount of zakat paid $(\alpha \mathrm{Y})$. The mustahiks' income is given in the equation as $[(1-\beta) \mathrm{Y}+\alpha \mathrm{Y}]$, representing the net mustahik income as the mustahiks' income $(1-\beta) Y$ plus the zakat received $(\alpha Y)$.

In the equation above, zakat is not treated the same as taxes but rather as a public consumption expenditure for the afterlife, despite the fact that the issued zakat can be useful for the social community. The above consumption equation model uses the Absolute Income Hypothesis model proposed by Metwally. According to this hypothesis, a person's consumption absolutely depends on their current income. This is in line with the existing theory, where a mustahik's consumption is very dependent on the amount of income that is received today (Al-Arif, 2010).

Furthermore, Iqbal (1985) explains the model proposed by Darwish and Zain to correct the technical mistake proposed by Ausaf and Metwally. As such, in order to study the effect of zakat, one should not start with a consumption function like $\mathrm{C}=$ $a+b Y$ for a capitalist economy and then seek to bifurcate it for the Islamic economy, because in this function " $b$ " represents the MPC of both groups (muzakki and mustahik). In order to produce a meaningful comparison, one should instead begin with a function such as: 


$$
C_{S}=a+c(\beta Y)+d(1-\beta) Y
$$

where $\mathrm{c}$ and $\mathrm{d}$ are the MPC of the muzakki and mustahik respectively, so that the corresponding function in an Islamic economy would be:

$$
C_{I}=a+c[\beta Y-\alpha Y]+d[(1-\beta) Y+\alpha Y]
$$

\section{The Role of Zakat in the Economy}

Zakat plays an important role in reducing poverty. This is in line with the word of Allah in the Surah at-Taubah verse 60, where it is stated that the main target of zakat is the poor and needy. The members of this group have an income level less than the amount required to satisfy their needs, or consumption. The poor as a group comprise those who have no property or work; thus, they are unable to meet their basic needs and the basic needs of their dependents, while the needy are those who have property and work but in amounts that are insufficient to meet their own basic needs and those of their dependents.

In the context of microeconomics, zakat is thus a means for these people to meet their needs and to increase mustahiks' income. Whereas in the macroeconomic context, zakat constitutes a means of income distribution to eliminate the economic disparities that exist between upper-class and lower-class income economies. If zakat is managed in a systematic and well-organized way, it will produce a significant multiplier effect that leads to an increase in national income due to the acceleration of money circulation in the country's economy (Nasrullah, 2010). This is in line with the provisions of the following verse and hadith.
"The likeness of those who spend their wealth in Allah's way is as the likeness of a grain which groweth seven ears, in every ear a hundred grain. Allah giveth increase manifold to whom He will. Allah is All-Embracing, All-Knowing." (Q. al-Baqarah 2:261)

"From Ibn Abbas RA narrated from Rasulullah SAW, he said what he received from his Lord, Allah azza wa jalla. 'Verily Allah establishes good and evil and then explains it; whoever intends to do good and does not do so, Allah records on His side a perfect goodness. If he intends to do good then he actually does it, God will record by his side ten goodness up to seven hundred times even still doubled again. If he intended to do evil but did not do so Allah recorded it as a goodness. And if he intends to do evil then he actually does it, then Allah only records on His side a vice." "(Bukhari and Muslim)

The verse and hadith above implicitly illustrate the zakat multiplier effect, which occurs when zakat is given in consumptive form. Consumptive zakat that is given to mustahik will increase their purchasing power of the goods/services that constitute their needs. This increased purchasing power of goods/services will in turn affect companies' level of production, the impact of which will be the addition of production capacity, which means the company will take on more manpower. Meanwhile, an increase in production will increase the taxes that companies pay to the state. If state revenues increase, then the state will be able to provide facilities and infrastructure for development and be able to provide public facilities for the community (Al-Arif, 2010). 
Figure 1. Multiplier Effect of Zakat in the Economy

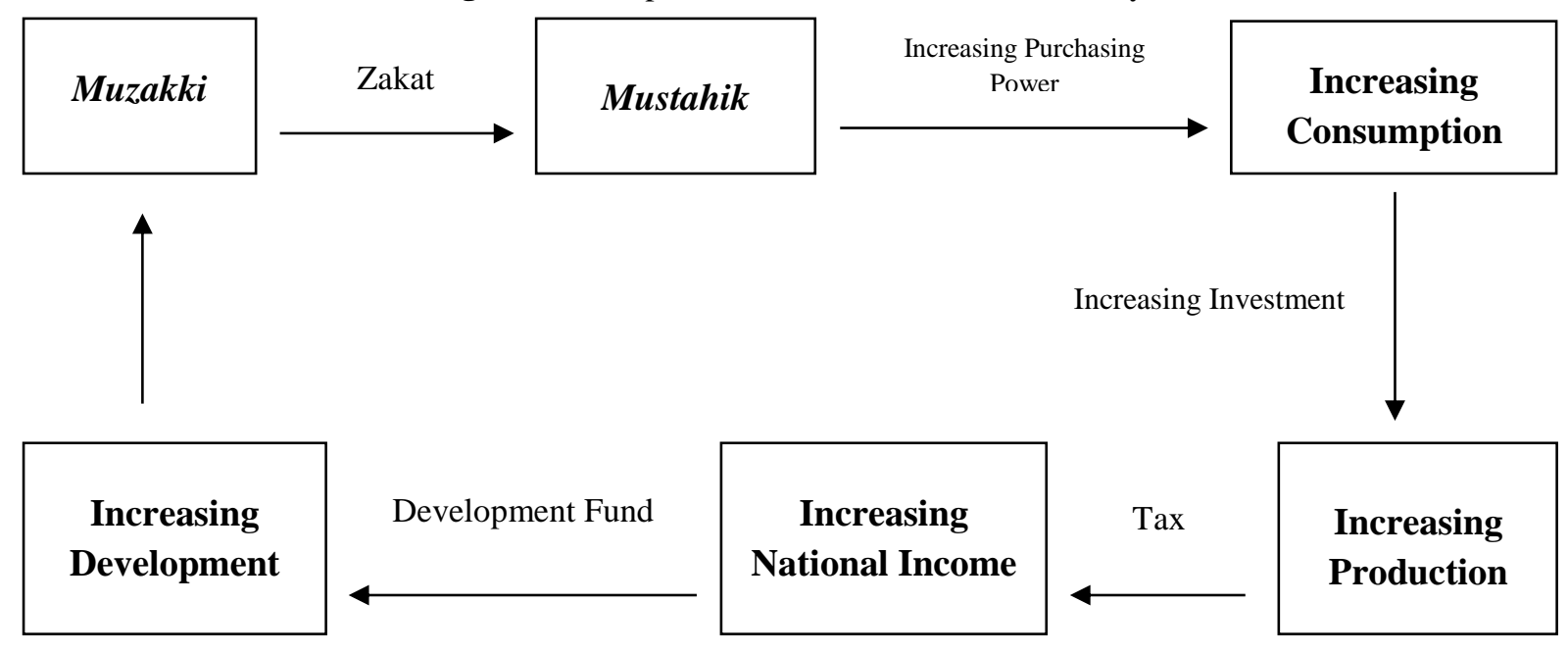

Source: Al-Arif, 2010

Figure 1 above shows that the payment of zakat can produce a multiplier effect in the economy that ultimately impacts the community indirectly. Zakat that is distributed solely in its consumptive form is able to generate a significant multiplier effect, while that distributed as productive zakat, such as in the form of venture capital or revolving funds, will certainly produce a larger multiplier effect in the economy since productive zakat has a greater effect than zakat in the consumptive form (Nasrullah, 2010). Zakat distributed to people in need will have a proportionately greater effect on aggregate demand owing to the fact that the consumption needs of this group are relatively larger, yet it should also be realized that the strategic role of zakat will nevertheless be realized if Moslems truly believe in and perform zakat correctly. In addition, there should be a strong belief instilled about the importance of zakat obligations, both in order to establish a vertical relationship with Allah SWT and to realize prosperity fairly within community life (Hayati, 2009).

Zakat plays a role in ensuring the wheels of the economy continuously turn and do not stop. Zakat serves as an instrument to overcome the socioeconomic problems of lower-class society whose needs must be met in both real time and in the short term. Zakat is a push factor in improving the condition of society, especially in economic terms, since it is through the distribution of zakat that the welfare growth of the wider society can be realized. If the zakat is well managed, as exemplified by Prophet Muhammad SAW, then it will lead to improvements in the welfare of society, reduce unemployment, and reduce the number of the poor and needy (Khasanah, 2010).

Based on the above explanation, it can be concluded that zakat has an important role in both the micro and macro economy, in both its consumptive and productive forms, as well as for muzakki and mustahik. Therefore, the professional, trustworthy, and transparent management of zakat needs to be improved and ensured in order to generate improvements to economic development and community welfare.

\section{RESEARCH METHODOLOGY}

This research uses a quantitative approach. The data were collected from March to May 2017 in Probolinggo Municipality. The methods used to collect the data were interview, questionnaire, and documentation. The subject of this research is the mustahik of BAZNAS Probolinggo Municipality as the main respondents, and 
the management of BAZNAS Probolinggo Municipality as the supporting respondents. The population of this study is all BAZNAS Probolinggo Municipality mustahik from the poor and needy group, both consumptive and productive zakat recipients, which gives a total of 100 people. The sampling technique used is Proportional Random Sampling. The total sample size required for this research was 50 people, comprising 16 recipients of consumptive zakat and 34 recipients of productive zakat. Path analysis was used to determine the direct and indirect effect of zakat on mustahiks' household consumption. Two structural equation models were used in the path analysis: Path I and Path II.

$$
\begin{gathered}
\mathrm{Y}_{1}=\mathrm{a}_{1} \mathrm{X}_{1}+\mathrm{a}_{2} \mathrm{X}_{2}+\mathrm{a}_{3} \mathrm{X}_{3}+\mathrm{a}_{4} \mathrm{X}_{4}+\mathrm{a}_{5} \mathrm{e}_{1} \\
(\mathrm{Path} \mathrm{I}) \\
\mathrm{Y}_{2}=\mathrm{b}_{1} \mathrm{X}_{1}+\mathrm{b}_{2} \mathrm{X}_{2}+\mathrm{b}_{3} \mathrm{X}_{3}+\mathrm{b}_{4} \mathrm{X}_{4}+\mathrm{b}_{5} \mathrm{Y}_{1}+ \\
\mathrm{b}_{6} \mathrm{e}_{2}
\end{gathered}
$$

(Path II)

$\mathrm{Y}_{1}$ : income (household income, in rupiahs)

$\mathrm{Y}_{2}$ : consumption (household consumption, in rupiahs)

$\mathrm{X}_{1}$ : zakat received (in rupiahs)

$\mathrm{X}_{2}$ : number of household members (in persons)

$\mathrm{X}_{3}$ : education (head of household's education, in years)

$\mathrm{X}_{4}$ : age (head of household's age, in years)

$\mathrm{e}_{1}, \mathrm{e}_{2} \quad$ : error

$a_{1-4}, b_{1-5}:$ path coefficients

$a_{5}, b_{6} \quad$ : residual coefficient.

The structural equation model of "Path I" aims to analyze the effect of exogenous variables, i.e., zakat received, number of household members, education, and age, on an intermediate variable, i.e. income. The structural equation model of "Path II" aims to analyze the effect of exogenous variables, i.e., zakat received, number of household members, education, age, and income, on an endogenous variable, i.e. consumption. The estimation results were analyzed using path analysis assumption tests (normality and linearity test), model validity tests (coefficient of total determination and whole model test), and significance tests (coefficient of determination, $\mathrm{F}$ test, and t-test).

\section{RESULTS \& DISCUSSION}

\section{Overview of BAZNAS Probolinggo Municipality}

National Board of Zakat (BAZNAS) Probolinggo Municipality is an institution in charge of collecting, distributing, and utilizing zakat and infaq/alms in Probolinggo Municipality. The office of BAZNAS Probolinggo Municipality is located on the second floor of the Islamic Center Building, Basuki Rahmad Street, Probolinggo, East Java.

Based on Law Number 38 Year 1999 on Zakat Management, a small team was formed to complete the regulation on the zakat board that formed the Regional Regulation Draft on Zakat Management so that in 2010, Regional Regulation Number 11 Year 2010 on the Zakat Management could be legalized by the Regional House of Representatives. Following the above regulation, Decree of Probolinggo Mayor Number 188.45/84/KEP/425.012/2011 on the Management of BAZNAS Probolinggo Municipality was issued and became the forerunner to the founding of BAZNAS Probolinggo Municipality. Once the board had been formed, work was undertaken over a period of approximately one year to map the potential of the muzakki and mustahik in each village and socialization on each Work Unit and at educational institutions. Furthermore, in May 2012, the "Zakat Conscious Movement" was inaugurated by the Probolinggo Mayor (BAZNAS Probolinggo Municipality, 2016). 
Estimation Results

With the help of the Statistical Product and Service Solution (SPSS) program, a summary of the structural equation modeling estimation results for Path I and Path II is shown in the following table:

Table 2. Estimation Results of Path Analysis

\begin{tabular}{|c|c|c|c|c|c|c|c|}
\hline \multicolumn{3}{|c|}{ Path I } & \multicolumn{5}{|c|}{ Path II } \\
\hline $\begin{array}{c}\text { Independent } \\
\text { Variable }\end{array}$ & $\begin{array}{c}\text { Standar- } \\
\text { dized } \\
\text { Coeffi- } \\
\text { cients } \\
\text { Beta }\end{array}$ & $\mathbf{t}$ & Sig. t & $\begin{array}{c}\text { Independent } \\
\text { Variable }\end{array}$ & $\begin{array}{c}\text { Standar- } \\
\text { dized } \\
\text { Coeffi- } \\
\text { cients } \\
\text { Beta }\end{array}$ & $\mathbf{t}$ & Sig. $t$ \\
\hline $\mathrm{X}_{1}$ & 0.263 & 1.777 & $0.082 * *$ & $\mathrm{X}_{1}$ & 0.193 & 1.839 & $0.073 * *$ \\
\hline $\mathrm{X}_{2}$ & 0.367 & 2.327 & $0.025^{*}$ & $X_{2}$ & 0.554 & 4.844 & $0.000 *$ \\
\hline$X_{3}$ & $0 . \overline{285}$ & $\overline{-}$ & 0.134 & $\mathrm{X}_{3}$ & 0.015 & 0.114 & 0.910 \\
\hline \multirow[t]{2}{*}{$X_{4}$} & 0.134 & $0 . \overline{-}$ & 0.468 & $\mathrm{X}_{4}$ & $\begin{array}{c}- \\
0.051\end{array}$ & 0.403 & 0.689 \\
\hline & & & & $Y_{1}$ & 0.225 & 2.198 & $0.033^{*}$ \\
\hline
\end{tabular}

Independent Variable: $\mathrm{Y}_{1}$ Independent Variable: $\mathrm{Y}_{2}$

$F=3.286$; Sig. $F=0.019 ; R^{2}=0.226$ $F=15.920 ;$ Sig. $F=0.000 ; R^{2}=0.664$

$*$ : Significant at the 0.05 level

**: Significant at the 0.10 level

Source: Data Analysis Results, 2017

Prior to analyzing the estimation results, it is first necessary to test the path analysis assumption.

\section{Path Analysis Assumption Test}

Based on one of the basic assumptions of path analysis, the relationship between variables is normal and linear (Riduwan \& Kuncoro, 2011); it is thus necessary to test the normality and linearity when conducting path analysis. A normality test is conducted using the Kolmorogov-Smirnov (K-S) test, while the linearity test is seen from the Sig. value in deviation from linearity. The following table contains a summary of the normality and linearity test results.

Table 3. Results of the Path Analysis Assumption Test

\begin{tabular}{|c|c|c|c|}
\hline \multicolumn{4}{|c|}{ Normality Test } \\
\hline \multicolumn{2}{|c|}{ Path I } & \multicolumn{2}{|c|}{ Path II } \\
\hline $\begin{array}{l}\text { Asymp. Sig. (2- } \\
\text { tailed) }\end{array}$ & 0.166 & $\begin{array}{l}\text { Asymp. Sig. (2- } \\
\text { tailed) }\end{array}$ & 0.971 \\
\hline \multicolumn{4}{|c|}{ Linearity Test } \\
\hline \multicolumn{2}{|c|}{ Path I } & \multicolumn{2}{|c|}{ Path II } \\
\hline Variable & $\begin{array}{c}\text { Sig. Value on } \\
\text { Deviation from } \\
\text { Linearity }\end{array}$ & Variable & $\begin{array}{c}\text { Sig. Value on } \\
\text { Deviation from } \\
\text { Linearity }\end{array}$ \\
\hline $\mathrm{X}_{1}$ with $\mathrm{Y}_{1}$ & 0.796 & $\mathrm{X}_{1}$ with $\mathrm{Y}_{2}$ & 0.449 \\
\hline $\mathrm{X}_{2}$ with $\mathrm{Y}_{1}$ & 0.224 & $\mathrm{X}_{2}$ with $\mathrm{Y}_{2}$ & 0.557 \\
\hline
\end{tabular}




$\begin{array}{llll}\mathrm{X}_{3} \text { with } \mathrm{Y}_{1} & 0.000 & \mathrm{X}_{3} \text { with } \mathrm{Y}_{2} & 0.133 \\ \mathrm{X}_{4} \text { with } \mathrm{Y}_{1} & 0.772 & \mathrm{X}_{4} \text { with } \mathrm{Y}_{2} & 0.523 \\ & & \mathrm{Y}_{1} \text { with } \mathrm{Y}_{2} & 0.157\end{array}$

Source: Data Analysis Results, 2017

Based on the normality test results obtained, the Asymp. Sig. value (2-tailed) for Path I is 0.166 and for Path II is 0.971 . These are both higher than the significance level of $0.10(\alpha=10 \%)$, indicating that the residuals in the Path I and Path II models are normally distributed.

From the linearity test, the Sig. value on Deviation from Linearity is known. In Path I, the Sig. values for the variables $X_{1}$, $\mathrm{X}_{2}$, and $\mathrm{X}_{4}$ with $\mathrm{Y}_{1}$ are $0.796,0.224$, and 0.772 , respectively. The values are all higher than the significance level of 0.10 $(\alpha=10 \%)$, thus indicating that the relationship between the variables is linear. The sig. value for variable $\mathrm{X}_{3}$ with $\mathrm{Y}_{1}$ is 0.000 , which means the relationship between variable $X_{3}$ and $Y_{1}$ is not linear. It can thus be concluded that the relationship between the exogenous and endogenous variables of Path I as a whole is linear. In Path II, the Sig. values of variables $X_{1}, X_{2}$, $\mathrm{X}_{3}, \mathrm{X}_{4}$, and $\mathrm{Y}_{1}$ with $\mathrm{Y}_{2}$ are $0.449,0.557$, $0.133,0.523$, and 0.157 , respectively. Each of the Sig. values is higher than the significance level of $0.10(\alpha=10 \%)$, which means that the relationship between the variables is linear. It can thus be concluded that the relationship between the exogenous and endogenous variables as a whole is linear.

\section{Model Validity Test}

The model validity test is seen from two indicators, namely the coefficient of total determination and the whole model test. The results are shown in the following table.

Table 4. Results of the Model Validity Test

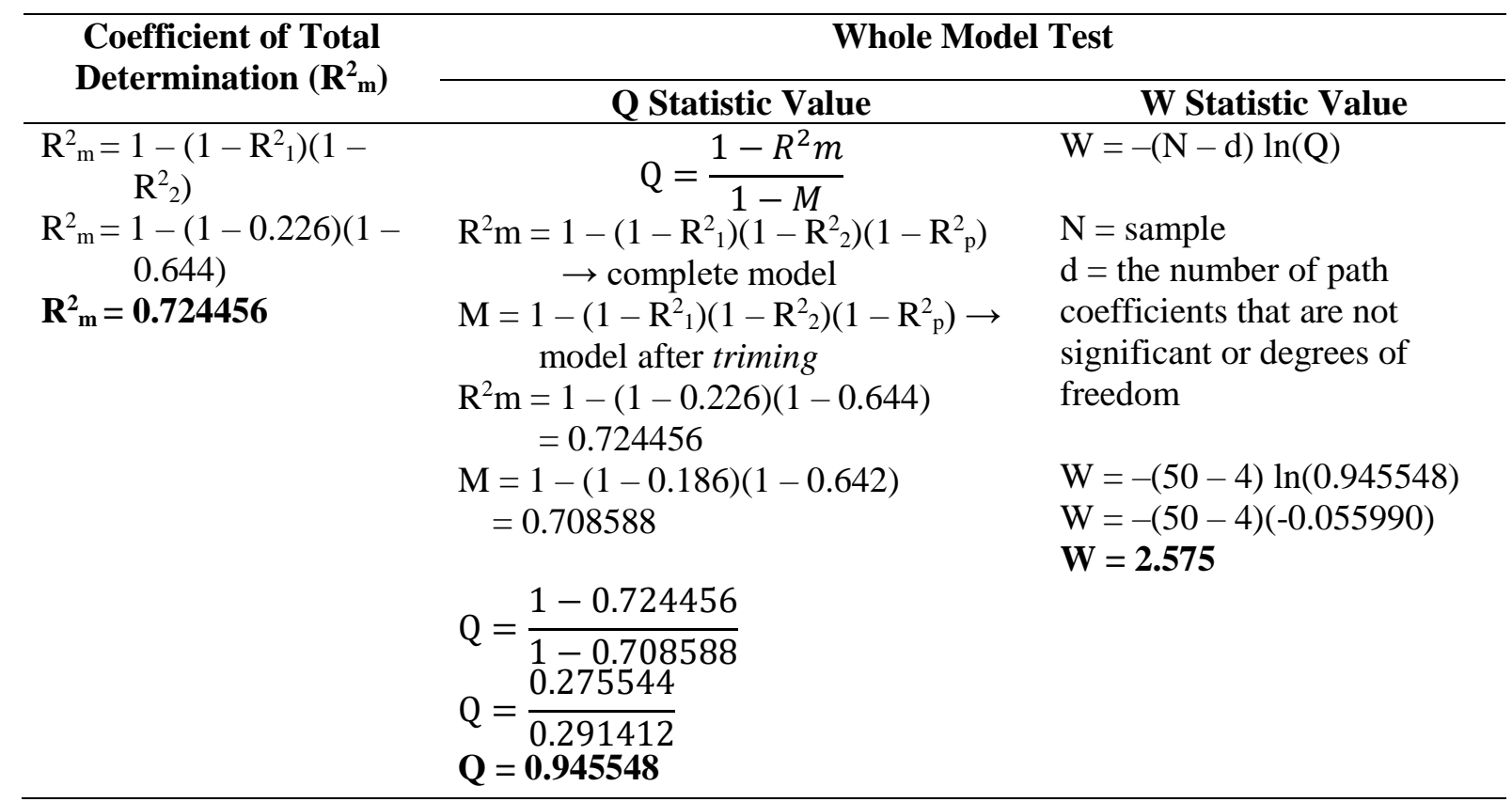

Source: Data Analysis Results, 2017

The coefficient of total determination is 0.724456 . That is, the diversity of data that can be explained by the path analysis model, either Path I or 
Path II, of 0.724 , or the $72.4 \%$ variation of consumption variable, can be explained by the variables of zakat received, the number of household members, education, age, and income, while the remainder is explained by other factors not found in the model. The Q statistic value of 0.945 shows a high value since $Q$ is approaching 1; it can thus be said that the model has a high degree of compatibility with the data. The value from the Chi-Square table for 4 degrees of freedom and $\alpha=10 \%$ is 7.78. The $\mathrm{W}$ statistic value $(2.575)<$ Chi-Square table (7.78), which means the proposed model fits the empirical data. Based on these results, it can be concluded that the path analysis model, comprising both Path I and Path II, is valid.

\section{Significance Test}

A significance test is performed to analyze the effect of exogenous variables on endogenous variables both simultaneously and partially/individually. The basis of the test uses a significance value of $0.1(\alpha=$ $10 \%)$. The result of the effect of exogenous variables on endogenous variables can be seen in Table 2 .

\section{a. Path I (Income as Endogenous Variable)}

The simultaneous test (F test) of Path I was conducted to know the effect of zakat received $\left(\mathrm{X}_{1}\right)$, number of household members $\left(\mathrm{X}_{2}\right)$, education $\left(\mathrm{X}_{3}\right)$, and age $\left(\mathrm{X}_{4}\right)$ on income $\left(\mathrm{Y}_{1}\right)$ simultaneously. The simultaneous effect of $\mathrm{X}_{1}, \mathrm{X}_{2}, \mathrm{X}_{3}$, and $\mathrm{X}_{4}$ on $\mathrm{Y}_{1}$ can be seen from the Sig. F value, which is 0.019 , less than the significance value of 0.10 . Thus, it can be concluded that zakat received, number of household members, education, and age simultaneously have a significant effect on income. The coefficient of determination $\left(\mathrm{R}^{2}\right)$ value of 0.226 means that the variables of zakat received, number of household members, education, and age can explain the $22.6 \%$ change in income variable, while the rest is explained by other factors/variables not discussed in this study. The magnitude of the residual coefficient is as $=\sqrt{1-0.226}=0.879$.

A partial test (t-test) of Path I was conducted to determine the effect of $X_{1}$, $\mathrm{X}_{2}, \mathrm{X}_{3}$, and $\mathrm{X}_{4}$ on $\mathrm{Y}_{1}$ individually. The $\mathrm{t}-$ test can be seen from each Sig. $t$ value of the independent variables. The partial effect of $\mathrm{X}_{1}$ on $\mathrm{Y}_{1}$ is 0.263 with a Sig. $\mathrm{t}$ value of 0.082 , which is less than the significance value (0.10). The partial effect of $\mathrm{X}_{2}$ on $\mathrm{Y}_{1}$ is 0.367 with a Sig. $t$ value of 0.025 , which is less than the significance value. The partial effect of $\mathrm{X}_{3}$ on $\mathrm{Y}_{1}$ is 0,285 with a Sig. $t$ value of 0.134 , which is greater than the significance value. The partial effect of $\mathrm{X}_{4}$ on $\mathrm{Y}_{1}$ is $-0,134$ with a Sig. $t$ value of 0.468 , which is greater than the significance value. It can thus be concluded that zakat received and number of household members have a partially significant effect on income, while education and age have no partially significant effect on income.

The above results show that in Path $\mathrm{I}, \mathrm{X}_{1}, \mathrm{X}_{2}, \mathrm{X}_{3}$, and $\mathrm{X}_{4}$ simultaneously have a significant effect on $Y_{1}$. Partially, there is a path coefficient, which is not significantly affected, that is $\mathrm{X}_{3}$ and $\mathrm{X}_{4}$. Thus, Path I needs to be improved using the trimming method by removing the $\mathrm{X}_{3}$ and $\mathrm{X}_{4}$ variables from Equation $\mathrm{I}$ and reestimating without them. The results are shown in the following table. 
Table 5. Estimation Results of Path I After the Trimming Method

\begin{tabular}{|c|c|c|c|c|c|c|}
\hline & \multirow{2}{*}{ Model } & \multicolumn{2}{|c|}{ Unstandardized Coefficients } & \multirow{2}{*}{\begin{tabular}{c|}
$\begin{array}{c}\text { Standardized } \\
\text { Coefficients }\end{array}$ \\
Beta
\end{tabular}} & \multirow{2}{*}{$\mathbf{t}$} & \multirow{2}{*}{ Sig. } \\
\hline & & B & Std. Error & & & \\
\hline \multirow[t]{3}{*}{1} & (Constant) & -323127.418 & 642662.954 & & -.503 & .617 \\
\hline & $\mathrm{X}_{1}$ & 1.031 & .612 & .236 & 1.685 & $.099 * *$ \\
\hline & $\mathrm{X}_{2}$ & 324083.260 & 156144.327 & .290 & 2.076 & $.043 *$ \\
\hline \multicolumn{3}{|c|}{ a. Dependent Variable: $\mathrm{Y}_{1}$} & $F=5.369$ & Sig. $F=0.008$ & $\mathrm{R}^{2}=0.186$ & \\
\hline
\end{tabular}

Based on the estimation result, the path coefficient value for zakat received is 0.236 and for number of household members is 0.290 , with a coefficient of determination of $\mathrm{R}^{2}=0.186$; residual coefficient of $\mathrm{a}_{5}=\sqrt{1-0.186}=0.902$; and Sig. F value of 0.008 .

\section{b. Path II (Consumption as Endogenous Variable)}

The simultaneous test (F test) of Path II was conducted to determine the effect of zakat received $\left(\mathrm{X}_{1}\right)$, number of household members $\left(\mathrm{X}_{2}\right)$, education $\left(\mathrm{X}_{3}\right)$, age $\left(\mathrm{X}_{4}\right)$, and income $\left(\mathrm{Y}_{1}\right)$ on consumption $\left(\mathrm{Y}_{2}\right)$ simultaneously. The simultaneous effect of $\mathrm{X}_{1}, \mathrm{X}_{2}, \mathrm{X}_{3}, \mathrm{X}_{4}$, and $\mathrm{Y}_{1}$ on $\mathrm{Y}_{2}$ can be seen from the Sig. F value, which is 0.000 , thus less than the significance value of 0.10 . It can therefore be concluded that zakat received, number of household members, education, age, and income simultaneously have a significant effect on consumption. The coefficient of determination $\left(\mathrm{R}^{2}\right)$ value of 0.664 means that the variables of zakat received, number of household members, education, age, and income can explain the change of consumption variable of $66.4 \%$, while the rest is explained by other factors/variables not discussed in this study. The size of the residual coefficient is $\mathrm{b}_{6}=\sqrt{1-0.644}=0.567$.
The partial test (t-test) of Path II was conducted to know the effect of $X_{1}$, $\mathrm{X}_{2}, \mathrm{X}_{3}, \mathrm{X}_{4}$, and $\mathrm{Y}_{1}$ on $\mathrm{Y}_{2}$ individually. The $t$-test can be seen from each Sig. $t$ value of the independent variables. The partial effect of $\mathrm{X}_{1}$ on $\mathrm{Y}_{2}$ is 0.193 with a Sig. $\mathrm{t}$ value of 0.073 , which is less than the significance value (0.10). The partial effect of $\mathrm{X}_{2}$ on $\mathrm{Y}_{2}$ is 0.554 with a Sig. $t$ value of 0.000 , which is less than the significance value. The partial effect of $\mathrm{X}_{3}$ on $\mathrm{Y}_{2}$ is 0.015 with a Sig. $t$ value of 0.910 , which is more than the significance value. The partial effect of $\mathrm{X}_{4}$ on $\mathrm{Y}_{2}$ is -0.051 with a Sig. $t$ value of 0.689 , which is more than the significance value. The partial effect of $\mathrm{Y}_{1}$ on $\mathrm{Y}_{2}$ is 0.225 with a Sig. $t$ value of 0.033 , which is less than the significance value. It can thus be concluded that zakat received, number of household members, and income have a partially significant effect on consumption, while education and age have no partially significant effect on consumption.

The above results show that in Path II, $\mathrm{X}_{1}, \mathrm{X}_{2}, \mathrm{X}_{3}, \mathrm{X}_{4}$, and $\mathrm{Y}_{1}$ simultaneously have a significant effect on $Y_{2}$. Partially, there is a path coefficient, which is not significantly affected, that is $\mathrm{X}_{3}$ and $\mathrm{X}_{4}$; thus, Path II needs to be improved through the Trimming Method by removing variables $\mathrm{X}_{3}$ and $\mathrm{X}_{4}$ from Equation II and re-estimating it without them. The results are shown in the following table. 
Table 6. Estimation Results of Path II After the Trimming Method

\begin{tabular}{|c|c|c|c|c|c|c|}
\hline & \multirow{2}{*}{ Model } & \multicolumn{2}{|c|}{ Unstandardized Coefficients } & \multirow{2}{*}{\begin{tabular}{|c|}
$\begin{array}{c}\text { Standardized } \\
\text { Coefficients }\end{array}$ \\
Beta \\
\end{tabular}} & \multirow{2}{*}{$\mathbf{t}$} & \multirow{2}{*}{ Sig. } \\
\hline & & B & Std. Error & & & \\
\hline \multirow[t]{4}{*}{1} & (Constant) & -29781.017 & 187102.715 & & -.159 & .874 \\
\hline & $\mathrm{X}_{1}$ & .404 & .183 & .213 & 2.209 & $.032 *$ \\
\hline & $\mathrm{X}_{2}$ & 280393.887 & 47369.758 & .580 & 5.919 & $.000 *$ \\
\hline & $\mathrm{Y}_{1}$ & .096 & .042 & .222 & 2.265 & $.028 *$ \\
\hline \multicolumn{3}{|c|}{ a. Dependent Variable: $\mathrm{Y}_{2}$} & $\mathrm{~F}=27.437$ & Sig. $F=0.000$ & $=0.642$ & \\
\hline
\end{tabular}

*: Significant at the 0.05 level

Source: Data Analysis Results, 2017

Based on the estimation result, the path coefficient value for zakat received is 0.213 ; number of household members is 0.580 ; and income is 0.222 , with coefficient of determination $\mathrm{R}^{2}=0.642$; residual coefficient $b_{6}=\sqrt{1-0.642}=$ 0.598 ; and Sig. F value of 0.000 .

The overall structural equation models after the Trimming Method are as follows:

$$
\begin{aligned}
\mathrm{Y}_{1}= & \mathrm{a}_{1} \mathrm{X}_{1}+\mathrm{a}_{2} \mathrm{X}_{2}+\mathrm{a}_{5} \mathrm{e}_{1} \\
= & 0.236 \mathrm{X}_{1}+0.290 \mathrm{X}_{2}+0.902 \mathrm{e}_{1} \\
\mathrm{Y}_{2}= & \mathrm{b}_{1} \mathrm{X}_{1}+\mathrm{b}_{2} \mathrm{X}_{2}+\mathrm{b}_{5} \mathrm{Y}_{1}+\mathrm{b}_{6} \mathrm{e}_{2} \\
= & 0.213 \mathrm{X}_{1}+0.580 \mathrm{X}_{2}+0.222 \mathrm{Y}_{1}+ \\
& 0.598 \mathrm{e}_{2}
\end{aligned}
$$

\section{Discussion}

The coefficient of total determination $\left(\mathrm{R}_{\mathrm{m}}^{2}\right)$ value of 0.724456 means that zakat received, number of household members, education, age, and income are able to explain $72.4 \%$ of the change in consumption, while the rest is explained by other factors/variables that are not discussed in this study. Simultaneously, zakat received, number of household members, education, age, and income have a positive and significant effect on consumption. Based on the calculation of path analysis, the magnitudes of the direct effect, indirect effect, and total effect of

\begin{tabular}{|c|c|c|c|c|c|}
\hline \multirow[b]{2}{*}{ Variables Effect } & \multicolumn{3}{|c|}{ Causal Effect } & \multirow{2}{*}{$\mathbf{R}^{2}$} & \multirow{2}{*}{$\begin{array}{c}\text { Residual } \\
\text { Coefficient }\end{array}$} \\
\hline & Direct & Indirect & Total & & \\
\hline $\mathrm{X}_{1}$ on $\mathrm{Y}_{1}$ & 0.236 & & & & \\
\hline $\mathrm{X}_{2}$ on $\mathrm{Y}_{1}$ & 0.290 & & & & \\
\hline $\mathrm{X}_{3}$ on $\mathrm{Y}_{1}$ & - & - & - & & \\
\hline $\mathrm{X}_{4}$ on $\mathrm{Y}_{1}$ & - & - & - & & \\
\hline$X_{1}$ and $X_{2}$ on $Y_{1}$ & & & & 0.186 & 0.902 \\
\hline $\mathrm{X}_{1}$ on $\mathrm{Y}_{2}$ & 0.213 & $0.236 \times 0.222=0.052$ & 0.265 & & \\
\hline $\mathrm{X}_{2}$ on $\mathrm{Y}_{2}$ & 0.580 & $0.290 \times 0.222=0.064$ & 0.644 & & \\
\hline $\mathrm{X}_{3}$ on $\mathrm{Y}_{2}$ & - & - & - & & \\
\hline $\mathrm{X}_{4}$ on $\mathrm{Y}_{2}$ & - & - & - & & \\
\hline $\mathrm{Y}_{1}$ on $\mathrm{Y}_{2}$ & 0.222 & & 0.222 & & \\
\hline$X_{1}, X_{2}$, and $Y_{1}$ on $Y_{2}$ & & & & 0.642 & 0.598 \\
\hline
\end{tabular}
the two path models are summarized in the following table.

Table 7. Summary of the Direct Effect, Indirect Effect, and Total Effect of the Exogenous Variables on the Endogenous Variables

Source: Data Analysis Results, 2017

Based on the above table, the overall path diagram can be determined as follows. 
Figure 2. Path Diagram

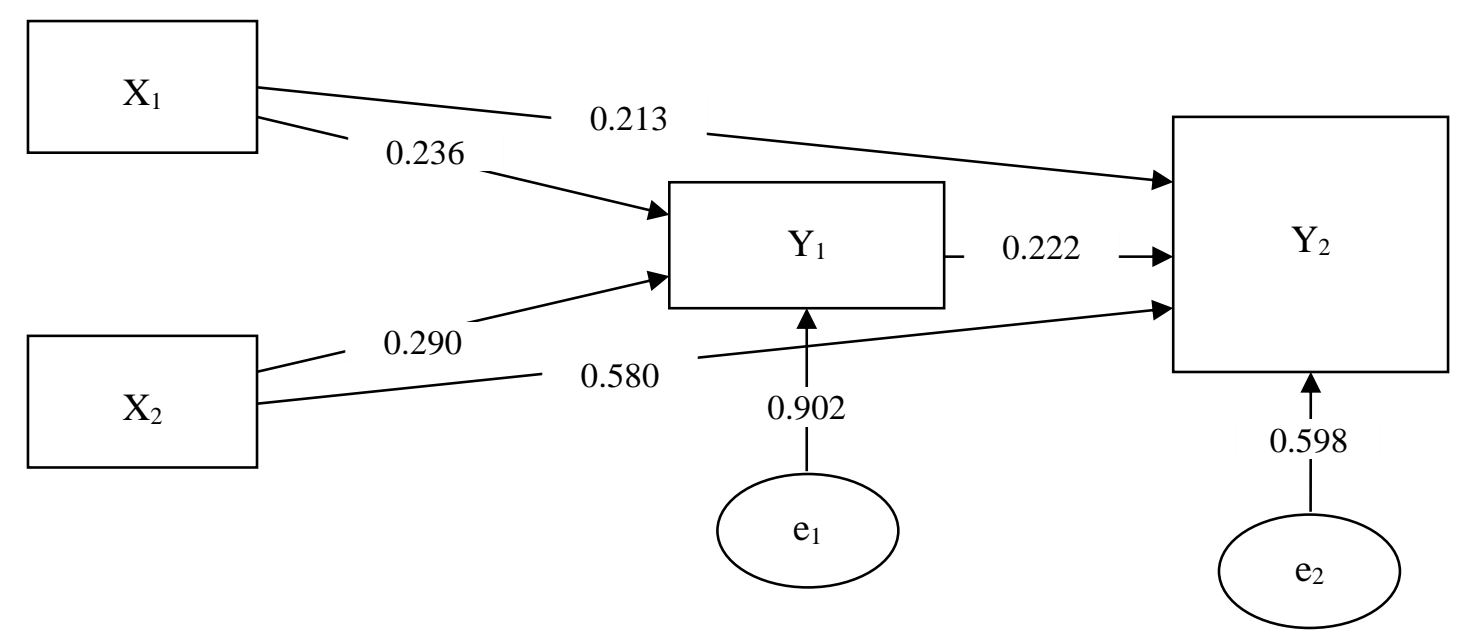

Source: Data Analysis Results, 2017

After analyzing the data, the direct and indirect effect of zakat received, number of household members, education, age, and income on consumption can be interpreted. Income $\left(\mathrm{Y}_{1}\right)$ has a significant effect on consumption $\left(\mathrm{Y}_{2}\right)$ and the effect is positive. This means that when income rises, consumption will also rise. This result is in accordance with Keynes's Consumption Theory. According to Keynes, consumption is affected by income. As income increases, so too does consumption, although consumption does not increase at the same rate as income. The path coefficient of income on consumption of 0.222 means that if the (standardized) income increases by one standard deviation, on average, the (standardized) consumption increases by about 0.222 standard deviations, ceteris paribus.

Zakat received $\left(\mathrm{X}_{1}\right)$ has a significant direct and indirect effect on consumption $\left(\mathrm{Y}_{2}\right)$ and the effect is positive. This means that if the zakat received by mustahik increases, then household consumption will also increase. This result is in accordance with the theory that when the amount of zakat received increases, so consumption will also increase. The path coefficient of zakat received on consumption of 0.213 means that if the (standardized) zakat received increases by one standard deviation, on average, then the (standardized) consumption increases by about 0.213 standard deviations, ceteris paribus. The zakat in this case is channeled for the household consumption of mustahik directly (i.e., it is consumptive zakat). Zakat received also has an indirect effect on consumption through income. The path coefficient of zakat received on consumption through income of 0.052 means that if the (standardized) zakat received were to increase by one standard deviation, on average, so the (standardized) consumption would increase by 0.052 standard deviations, ceteris paribus. The zakat in this case is channeled for productive purposes (productive zakat), i.e., zakat funds that are used as business capital for mustahiks to increase their income. The utilization of zakat for productive business is done when the basic necessity of mustahik has been fulfilled. This productive zakat will increase the production factor (capital) in the mustahik's business so as to increase output and income, and ultimately this increase in income will increase mustahiks' household consumption. Directly and indirectly, the effect of zakat received on consumption is 0.265 .

These results indicate that consumptive zakat has a greater effect than productive zakat. This is inversely proportional to the theory that productive 
zakat has a greater effect than consumptive zakat. The lower effect of productive compared to consumptive zakat is predicted to be caused by the absence of a mentoring/guidance program by BAZNAS Probolinggo Municipality, meaning that less effective use is made of the productive zakat. Some mustahik also make use of productive zakat for instantaneous consumption, some have encountered problems that mean their business activities have not run until now, while others have not utilized the capital goods received due to feeling they are lacking in expertise. Out of 34 mustahik recipients of productive zakat, only 19 have business activities that are still running to date.

The number of household members $\left(\mathrm{X}_{2}\right)$ has a significant direct and indirect effect on consumption $\left(\mathrm{Y}_{2}\right)$ and the effect is positive. This means that if the number of household members increases, then so too will household consumption increase. This result is in accordance with the theory that when the number of household members increases, so too will consumption increase. The path coefficient of the number of household members on consumption of 0.580 means that if the (standardized) number of household members increases by one standard deviation, on average, then the (standardized) consumption increases by about 0.213 standard deviations, ceteris paribus. The number of household members also has an indirect effect on consumption through income. The path coefficient of number of household members on consumption through income of 0.064 means that if the (standardized) number of household members increases by one standard deviation, on average, then the (standardized) consumption increases by 0.064 standard deviations, ceteris paribus. Directly and indirectly, the effect of number of household members on consumption is 0.644 .

Education $\left(\mathrm{X}_{3}\right)$ has no significant effect, either directly or indirectly, on consumption $\left(\mathrm{Y}_{2}\right)$. This means that a high level of head of household education does not produce any difference in household consumption. This result is inversely proportional to the theory that the higher a person's education, the greater their consumption. The reason for the absence of an education effect on consumption can be attributed to the mustahiks' jobs. Most of them (44\%) work as small traders, where there is no requirement for special education/skills such as that demanded in a profession such as doctor, teacher, architect, or other expert; as such, a high level of education has no effect on the household's income and consumption.

Age $\left(\mathrm{X}_{4}\right)$ has no significant effect, either directly or indirectly, on consumption $\left(\mathrm{Y}_{2}\right)$. This means that the increasing age of the head of household does not affect household consumption. According to the consumption theory in the Life Cycle Hypothesis, one's consumption pattern is divided into three periods. The first period is from 0 years of age to a certain age, when the person has not been able to generate his own income. This period is characterized as a period of dissaving (when the individual is partaking in consumption activities but is not generating any income). The second period is when someone is working (and thus generating his own income) until the time he no longer works, during which time he is partaking in some saving activity. The last period is when a person is in old age and is no longer able to generate his own income, thus making it another period of dissaving (Sudarman \& Algifari, 1992). Based on the data from the research results, it is known that $18 \%$ of the mustahik are at an unproductive age (> 64 years), while a further $18 \%$ of mustahik do not work. According to the theory, when a person is in old age (not productive) and cannot afford to generate their own income, they are thus dissaving as their level of consumption decreases. In this period a person's income and consumption do not increase in line with their age. 


\section{CONCLUSION}

Based on the data analysis, results, and discussion, it can be concluded that zakat received and number of household members both directly and indirectly affect the household consumption of mustahik. In addition, household income as an intermediate variable also affects the household consumption of mustahik, whereas the education and age of the head of household does not affect the household consumption of mustahik, either directly or indirectly. Based on these conclusions, some recommendations can be put forward, such as it is to be expected that BAZNAS Probolinggo Municipality reruns its empowerment programs through productive zakat. Furthermore, a mentoring/coaching program needs to be carried out at least every three months in order to identify the progress/constraints in mustahiks' businesses. Mentoring/ coaching needs to be implemented so that the use of zakat is channeled more effectively so as to provide greater benefits for mustahik. BAZNAS Probolinggo Municipality is expected to accommodate the mustahiks' needs related to their business activities, i.e., by providing production factors such as capital, productive goods (equipment/machinery), and skills. In this case, entrepreneurship training is needed to improve the mustahiks' skills. BAZNAS Probolinggo Municipality is expected to use the zakat and infaq/alms received effectively and efficiently so that the funds can provide great benefits for mustahik in particular and for the economy in general. Given that the independent/exogenous variables in this research are variables that affect consumption, it is hoped that the results of the research can be used as a reference for other researchers to further develop the area of study by considering other variables that have not been discussed in this study.

\section{REFERENCES}

Al-Arif, M. N. R. (2010). Efek pengganda zakat serta implikasinya terhadap program pengentasan kemiskinan. Jurnal Ekbisi Fakultas Syariah UIN Sunan Kalijaga Yogyakarta, 5(1), 42-49.

Amalia, A., \& Mahalli, K. (2012). Potensi dan peranan zakat dalam mengentaskan kemiskinan di Kota Medan. Jurnal Ekonomi dan Keuangan, 1(1), 70-87.

BAZNAS Probolinggo Municipality (2016). Profil BAZNAS Kota Probolinggo. Probolinggo: BAZNAS Probolinggo Municipality.

Hafidhuddin, D. (2002). Zakat dalam Perekonomian Modern. Jakarta: Gema Insani Press.

Hayati, M. (2009). Peran strategis zakat dalam fungsi kebijakan politik ekonomi di Indonesia. Jurnal TAPIs, 5(10), 37-52.

Iqbal, M. (1985). Zakah, moderation and aggregate consumption in an Islamic economy. Journal Research Islamic Economics, 3(1), 45-61.

Khasanah, U. (2010). Manajemen Zakat Modern: Instrumen Pemberdayaan Ekonomi Umat. Malang: UINMaliki Press.

Nasrullah, M. (2010). Peran zakat sebagai pendorong multiplier ekonomi. Jurnal Hukum Islam, 8(1), 108119.

Pambudi, H. A. (2013). Peranan zakat produktif dalam pemberdayaan masyarakat miskin (studi kasus pada Badan Amil Zakat (BAZ) Kabupaten Kebumen). Fokus Bisnis: $\quad$ Media Pengkajian Manajemen dan Akuntansi, 12(2), 70-82.

Peraturan Presiden Republik Indonesia Nomor 15 Tahun 2010 tentang Percepatan Penanggulangan Kemiskinan. 2010. Retrieved from 
www.bpkp.go.id/uu/filedownload/5 /4/1834.bpkp

Qur an, 2 (261).

Qur an, 9 (60).

Rahardja, P., \& Manurung, M. (2008). Pengantar Ilmu Ekonomi: Mikroekonomi dan Makroekonomi (edisi ketiga). Jakarta: Lembaga Penerbit Fakultas Ekonomi Universitas indonesia.

Riduwan, O., \& Kuncoro, E. A. (2011). Cara Mudah Menggunakan dan Memaknai Path Analysis (Analisis Jalur). Bandung: Alfabeta.

Statistics of Indonesia (2017). Kemiskinan. Retrieved from https://www.bps.go.id/subjek/view/ $\mathrm{id} / 23$

Statistics of Indonesia (2017). Statistical Yearbook of Indonesia, Jakarta: Statistics of Indonesia.

Statistics of Probolinggo Municipality (2016). Kota Probolinggo dalam Angka. Probolinggo: Statistics of Probolinggo Municipality.

Sudarman, A., \& Algifari (1992). Ekonomi Mikro-Makro: Teori, Soal, dan Jawaban (Edisi kedua). Yogyakarta: BPFE UGM.

Sukirno, S. (2011). Makroekonomi Teori Pengantar (edisi ketiga). Jakarta: PT RajaGrafindo Persada.

Sumar'in, S. (2013). Ekonomi Islam: Sebuah Pendekatan Ekonomi Mikro Perspektif Islam. Yogyakarta: Graha Ilmu.

Suprayitno, E., Kader, R. A., \& Harun, A. (2013). The impact of zakat on aggregate consumption in Malaysia. Journal of Islamic Economics, Banking and Finance, 9(1), 39-62.
Elok Nurlita

Brawijaya University

Indonesia

elok.nurlita@gmail.com

Marlina Ekawaty

Brawijaya University

Indonesia 